\title{
TO INTERVENE OR NOT TO INTERVENE? POSITIONS OF THE MEMBER STATES TOWARDS THE ARTICLE 18 OF THE EUROPEAN BORDER AND COAST GUARD PROPOSAL
}

\author{
Martin Hrabálek ${ }^{1}$ Sylvie Burianová ${ }^{2}$
}

\begin{abstract}
The paper is focused on how the "migration crisis" starting in 2015 in Europe have reshaped the attitude to the European level of border protection. The basic question is how different are the competences of European Border and Coast Guard Agency (EBCG) from the previous FRONTEX and what was the role sovereignty played in it. The paper has a character of a qualitative study where the authors compare the proposal for EBCG, mainly its Article 18 establishing the "right to intervene" in the proposal, with the final version of the document and analyzes the position of the Member states based on their posititions within the Council to the parts of the proposal that were most connected to sovereignty. The analysis is based on data collection from officials from various member states that were part of the negotiations. Apart from this "hidden agenda" the authors also analyze public statements by high-ranking government officials that often commented on the proposal.
\end{abstract}

KEY WORDS: European Union, borders, EBCG, migration crisis

\section{INTRODUCTION}

The pressure of the migration crisis led the European Union to seek a solution to various problems that were connected to it. One of the core problems perceived both by the European Commission and the member states was the weakness of the external borders of the Union. Although the European Union has established already in 2005 an agency that was responsible for the coordination of activities at external borders (FRONTEX), its competences were rather limited and inadequate faced to the challenges of EU border protection during the crisis.

\footnotetext{
1 Mgr. Martin Hrabálek, PhD. Department of Territorial Studies, Faculty of Regional Development and International Studies, Mendel University in Brno, Czech Republic, E-mail: martin.hrabalek@mendelu.cz.

${ }^{2}$ Mgr. Sylvie Burianová (Ph.D. Student), Faculty of Social Studies, Masaryk University, Brno, Czech Republic, E-mail: 363789@mail.muni.cz.
} 
Many authors have previously pointed out to the fact that FRONTEX suffers from lack of competences and is dependent on the member states (Rijpma, 2010; Ekelund, 2014; Cortinovis, 2015). Events in Greece where in the midst of the crisis the possibility for FRONTEX to fully operate within the territory of the country was severely limited due to the lack of will of the country to cooperate, would show that the member states themselves with their concerns over sovereignty might be a major problem to the protection of borders in the EU.

In December 2015 the Commission had tabled a proposal for a Regulation on the European Border and Coast Guard, a follow up Agency to FRONTEX. The urgency to solve the problem of protection of European borders was reflected in a very tight schedule where the Council and the Parliament were to adopt an important proposal in co-decision within the framework of 7 months. That only shows that strengthening of the competences of FRONTEX was perceived as a necessary part of the solution for migration crisis.

One of the crucial parts of the proposal was the Article 18 that stated that the „Agency would have a right to intervene in situations at the external border requiring urgent action on the basis of a Commission implementing decision". This Article raised serious concerns over Articles 4(2) TEU and 72 TFEU that make the member states responsible for their own internal security, making it both legally and politically controversial.

The aim of the article is to concentrate on the key part of the proposal connected to the state sovereignty and the transfer of competences to the European Commission/EBCG. The abovementioned Article 18 was a key part of the proposal that would change the balance more towards the Union level and give more powers to the Commission. In the paper we will discuss why this ambitious part of the Commission proposal did not succeed and what the positions of the member states towards it were. We will try to categorize the member states into three different groups - those that would support the Article 18, those that would be cautious and those who would openly criticize it. As for the position, we will use both those stated publicly by the key representatives of the member states and the positions in the Council formation while the proposal was discussed.

The structure of the article is following. In the first part we will present the nexus between the borders and state sovereignty. In the second part we will discuss the development of border cooperation and FRONTEX, including an important period before the Agency was established during which a number of ideas how the European level of border protection should function were presented, including different levels of competence transfers. These debates 
are important in order to provide historical overview of disagreement on the form and competences the European border agency should have, as these were directly tied to the state sovereignty of the member states. We then move to analyse the 2015 proposal for EBCG with regard to sovereignty, the talks including member states and Union institutions over the proposal and the final legal act.

For the positions of the member states within the Council we used data gathered from directly involved civil servants from different member states and the transcripts of the statements of the member states representatives during the working bodies meetings. Several interviews were conducted in the years 2017 and 2018 in order to reconstruct the debate on the issues covered in the Article. We also used the public statements of the representatives of the member states (mostly ministers of interior) as a way how to define a position of that particular member state, if possible.

\section{STATE SOVEREIGNTY, EUROPEAN UNION AND BORDERS}

Borders and border protection have been traditionally closely tied with the concept of state sovereignty as the first marks the territory of the state and the second enables to decide who is allowed to enter its territory and who is not. In the last few decades the traditional view was essentially contested, though, and large part of the discussion would be connected to the relation between nation-state sovereignty and the emergence of new power formations, such as European Union (Jones, 2017, p. 3).

The gradual development of European integration, including building of the Schengen area, led to the change of perception of borders, including the important division between internal and external borders within the Schengen area. As Rudolf puts it, „closure from outside Europe was deemed a necessary condition for general acceptance of openness within the European Union"(Rudolf, 2005 p. 11).

One of the main functions of borders is their control function, thus controlling who enters the territory. In the context of European integration and the building of the Schengen area "the idea behind softening borders in the Schengen zone is that internal frontiers become soft, while external ones are hard, effectively creating a larger zone of free movement, but one with sharper edges...so entry to the area is strictly controlled"(Grabbe, 2000, p. 527).

In the EU reality the above mentioned means that the states in the EU were generally ready to give up on the control of internal borders, retreating 
back to it only in the state that they perceive as emergency, such as the current migration crisis. At the same time, they concentrate much more on the control of the external borders and so far, were quite reluctant to pass their competences on the Union level, as will be noted further. All this then has connection to the existence of the Schengen area, where the states inside the area ore quite dependent on the level of protection provided by the frontline states that lie on the external border.

In the following text we will concentrate on the discussion over EU level of border protection in the past two decades, focusing also on the preFRONTEX era and the role sovereignty played while the Agency was being established. We will show that the role of the sovereignty was central to all the debates about fostering the mandate of the Agency since. Then we move to the debate on the establishing of EBCG and we will take a closer look on the role of sovereignty within it.

\section{DEVELOPMENT OF THINKING ABOUT EUROPEAN BORDER PROTECTION}

The abolishment of internal border controls between six member states of the EU signing the Schengen Agreement in 1985, and its subsequent incorporation in the communitarian law by the Treaty of Amsterdam, was reflected by the new policy priorities set in the area of freedom, security and justice. In the Tampere Programme from 1999 the European Council underlined "...the importance of the effective control of the Union's future external border's protection by specialised trained professionals..." (European Council, 1999, par. 25).

The growing interest in the common borders' protection was further driven by the terrorist attacks of September 2001 and the impending enlargement towards Central and Eastern Europe. The terrorist attacks had closely interlinked the migration and borders with the issue of security and reinforced widespread calls for stricter border controls (Neal, 2009, p 338; Jorry, 2007, p. 1). Large enlargement eastwards and to the Balkans was a source of atmosphere of uncertainty as the EU member states were rather sceptical about the capabilities of the acceding states to protect their borders. After the enlargement, a large part of the new common external border of the EU would be geographically found on their territories and the mistrust towards the new members and concern of a possible increase of irregular immigration were embodied in the view that the EU would have "more vulnerable" borders after the enlargement (Ekelund, 2014, p. 105; Hobbing, 2005 p. 2-3). 
The idea to create a common border guard was presented to the Council by Germany and Italy early in 2001. In the autumn of that year, a group of member states, led by Italy and comprising of Belgium, Germany, France and Spain, launched a feasibility study on "European Border Police" backed by the European Commission. The states who were in favour of creating a supranational unit guarding the borders perceived it as a way to ensure burden sharing and solidarity between the old and new member states and to improve personnel and technical cooperation. It was supposed to be a move towards deeper political integration (Monar, 2006; Carrera, 2010 , p. 2). Some of the member states were quite unenthusiastic in the debates about centralized European border police though. The most visible example of this reluctance was the United Kingdom (Zaiotti, 2008, p. 227). With the impossibility to find a strong solution before, in December 2001 the member states formulated the compromise in the Laeken Declaration, in which the Council and the Commission were given a mandate to "...work out arrangements for cooperation between services responsible for external border control and examine the conditions in which a mechanism or common services to control external borders could be created..." (European Council, 2001, par. 42). While governments of some member states had already been using the term "European border guard" or "European border police", the declaration carefully avoided such an expression (Monar, 2006), not to create the perception of building a strong European body that some of the member states opposed.

In May 2002 Commission relased Communication "Towards an integrated management of external borders". With the emphasis on the gradual development of border cooperation it tried to satisfy both the supporters of centralization and its opponents. While the communication was generally positively received, a few Member States were principally against the idea to create a communitary European border guard (Monar, 2006; Parkes, 2015, p. 64; Leonard, 2009, p. 378).

The same month the results of the Feasibility study led by Italy were presented in Rome. The study came up with more an intergovernmental model based on a polycentric network of national border forces since it had brought together national experts who largely had defended their national systems of border protection. Benelux, Austria, Germany, Italy and Spain supported the paper. (Monar, 2006; Wolff - Schout, 2013, p. 311).

The European Council discussed the topic of border guard in June 2003 and prompted the Commission to seek new institutional structures and mechanisms in order to improve border cooperation (Commission 
of European Communities 2003, p.3). This time, the Commission started to work on a proposal for the establishment of a border agency (Ekelund, 2014 , p. 106). The idea of creating a border guard was not favoured after 2002 but that does not mean that it was completely forgotten. What the debates in 2001 and 2002 nonetheless disclosed were the differing views of the actors on how far the political integration in the field of border management should be advanced. The Commission, trying to capitalize on the calls for more security measures after 2001, suggested its concept of centralised border guard but ultimately met with resistance from member states. Generally, the states were not convinced that the added value of creating a strong institution could compensate for the partial loss of their sovereignty (Hrabálek, 2010, p. 62 - 63).

\section{CREATING FRONTEX AS A COMPROMISE}

Neal describes the period between 2001 and 2003 as a "process of negotiation, accommodation and compromise between the Commission and the Council and negotiation, accommodation and compromise between the Member States in the Council" (Neal, 2009, 340). The result was the Council Regulation (EC) 2007/2004 establishing FRONTEX. The difference between the European Border Guard as envisioned by the Commission and the actual outcome of deliberations in the form of agency was quite substantial. Frontex was given the task of multilateral coordinating activities at the border, while the actual sovereignty over the borders in terms of day-to-day border management remained in the hands of member states (Kasparek, 2010, p. 123).

The fact that the states were not ready to give up their sovereignty in this regard, is obvious from the name of the agency alone. In the initial proposal the Commission designed the "European Agency for the management of operational cooperation at the external borders". The regulation that was later adopted after the negotiations with the Council establishes "European agency for the management of operational cooperation at the external borders of the Member States of the European Union" (Jeandesboz, 2008, p. 3). The Commission also proposed that Frontex should be overseen by Management Board comprising of twelve members representing member states and two members of the Commission (Commission, 2003, p. 25). The Council was not really inclined to this idea and argued that every member state should have its representative in the Management Board, what is the structure that was later adopted and implemented (Ekelund, 2014, p. 109). 
Overall, the member states were able to agree fairly quickly on the creation of the agency, which they could all control through the management board. Their positions were not challenged by the European parliament as at the time of approval of the proposal the Parliament could be only consulted (Leonard, 2009, p. 381).

Frontex was created as a compromise between the European Commission's plan for integrated border management under the leadership of European institution and the unwillingness of the states to give up control over their parts of common external border shared by the Schengen agreements (Kasparek, 2010, p. 123). The agency has emerged as a politically acceptable answer to bridge the full regulatory communitarization border management on the one hand and pure intergovernmental approach on the other hand (Pollak-Slominski, 2009, p. 909). The compromise embodied in the agency's mandate can be observed at two levels. The first one is the compromise between the Commission's vision and the vision of the Council as a whole. This level can be described as an inter-institutional and clearly the position of the Council prevailed in the negotiations. The second, intrainstitutional level can be characterized by clash of member states' differing opinions in the inside of the Council. The main proponents of a strong agency were the states who were affected by an increased influx of illegal migration and who expected for the agency to reduce their burden, such as Spain and Italy, plus the states, who as destination countries relied on the protection of common border, such as most notably Germany. However, during the negotiations in the Council, these countries were forced to compromise on their demands and accept the agency in a form that the more conservative states emphasising their territorial sovereignty would agree on (Hrabálek, 2010, p. 64).

Although the agency was established under the first pillar, its performance and competences were guided by a strong intergovernmental logic. Frontex from its start largely depended on the willingness of member states to provide it with equipment and to participate in joint operations, which quickly became the predominant activity of the Agency (Carrera, 2010, p. 23).

The positive impact of Frontex activities on EU border management was recognized swiftly (Cortinovis, 2015, p. 257). Nevertheless, from the start there had been numerous calls for strengthening the agency's accountability and extending its mandate. The European Commission and the European Parliament have always been the proponents of the extension of the mandate of Frontex as they traditionally shared the view that the EU's 
external border is constituted by the common Schengen border and thus should be overlooked by a supranational actor (Parkes, 2015, p. 55-56). Even the member states called for the agency to be more powerful, however as Carrera notes, were then reluctant to grant Frontex more powers and autonomy during the negotiations in Council (Carrera, 2010, p. 23).

The debates revolved mainly around the provision of technical equipment and personnel to the agency by member states and its responsibility and accountability within the implemented joint operations. The European Union has sought to reflect the perceived shortcomings by adopting amendments to the Regulation in 2007, 2013 and 2014. The creation of Rapid Border Intervention Teams (RABITs), which introduced the element of "compulsory solidarity" in urgent and exceptional pressure, and subsequently the European Border Guard Teams (EBGT) for the deployment not only in rapid interventions but also in joint operations can be understood as a step in the process of evolution of border guards (Mungianu, 2013, p. 380).

\section{MIGRATION CRISIS - CHANGING CONTEXT}

Since the year 2010 the EU had to cope with an increased migratory pressure mainly on the southern external borders due to the outbreak of military conflicts in a number of states (civil conflicts in Libya, Syria, Iraq) (Ramboll \& Eurasylum, 2015, p. 101). Reflecting the change in the primary law in the Lisbon Treaty, which codified the objective of "the gradual introduction of an integrated management system for external borders" in the Article 77 (1) (c) TFEU, the European Council invited the Commission "to initiate a debate on the long-term development of FRONTEX". In 2013 the Unisys contracted by Commission conducted a feasibility study on the creation of a European System of Border Guards. According to the study's results, the majority of member states supported the increasing role of Frontex in EU border management but still considered the idea of centralised European border guard as premature (Unisys, 2014, p. 17-18). The year 2015 marked another challenge for the EU, as between January and November nearly 1, 5 million of people have crossed the external EU borders illegally (Commission, ESBG Proposal: 2). The European Agenda on Migration adopted by the Commission in May 2015, a political programme outlining priorities in the European migration, asylum and border policies, identified as one of the short-term goals to triple the capacities and the budget of Frontex (European Commission, 2015a). In the Commission's work programme "No time business as Usual" the Commission declared 
its aim to prepare the proposal to develop Frontex "into a fully operational European Border and Coast guard system" in accordance with the Juncker's State of the Union Speech from September 2015 (European Commission, 2015b, p. 11; European Commission, 2015c). The Commission's Proposal for the creation of a European Border and Coast Guard was presented in December 2015 and approved in September 2016. The European Border and Coast Guard Agency was officially launched in October 2016.

\section{SOVEREIGNTY IN THE EBCG PROPOSAL}

The proposal for EBCG, presented on $15^{\text {th }}$ December 2015, moved the relation between the European and national border protection competences further towards a stronger role of the European Commission. In its Article 18 (1) it said:

"Where a Member State does not take the necessary corrective measures in accordance with a decision of the Management Board referred to in Article 12(6) or in the event of disproportionate migratory pressure at the external border, rendering the control of the external borders ineffective to such an extent that it risks putting in jeopardy the functioning of the Schengen area, the Commission, after consulting the Agency, may adopt a decision by means of an implementing act, identifying the measures to be implemented by the Agency and requiring the Member State concerned to cooperate with the Agency in the implementation of those measures. Those implementing acts shall be adopted in accordance with the examination procedure referred to in Article 79(2).

On duly justified imperative grounds of urgency relating to the functioning of the Schengen area, the Commission shall adopt immediately applicable implementing acts in accordance with the procedure referred to in Article 79(5)."

This article would strengthen the possibility to intervene in reluctant member states, based on the decision of the Commission. Partially its inclusion was formed by the previous experience with Greece from year 2015. Although the country was under serious pressure during that year, for a long time it was not very willing to accept more help from FRONTEX and so there was certain level of disagreement between Greece and other member states (Reuters, 2015). 
During the presentation of the text at the working group of the Council the Commission said that it didn't expect this ever to be applied as there was significant number of steps preceding its application. As such, the Commission declared it did not see that Article affected the sovereignty of the member states.

The possibility of use of the right to intervene proposed in Article 18 was rather "crisis-driven” and the new system „would therefore not establish a permanent and stable deployment of European border guard teams along all EU external common borders, irrespective of the level of 'vulnerability" (Carrera - den Hertog, 2016, p. 12). But shortly after the proposal on ECBG was put on the table, some of the high officials of EU member states have openly voiced their concern over this part of the proposal affecting their sovereignty. Before we proceed with the positions of the member states within Council, we will provide few examples of the open critics of the "right to intervene".

Polish Foreign Minister Witold Waszcykowski told on a Polish radio that the "border troops have no democratic legitimacy" and that the proposal "would create an organisation that could arbitrarily make decisions about member states without giving them any voice in the process." (WSWS.org, 2015). Greek Alternate Foreign Minister for European Affairs Nikos Xydakis also openly questioned the Article 18 saying that "it touches the core of national sovereignty and European treaties" (Euractiv, 2015). Swedish Interior Minister Anders Ygeman was also among those that would be rather sceptical about the intervention mechanism, as he said that "border control is the competence for the member states, and it's hard to say that there is a need to impose that on member states forcefully" (Politico.eu, 2015b).

Spanish Minister of Interior Jorge Fernández Díaz was also very sceptical to the proposal, as he said it would "serve for nothing". He would base his argument on sovereignty of each member state to guard its borders and he would also point out that the time schedule was too fast for such a delicate proposal (EPNacional.es, 2015).

Between the open supporters of Article 18 we could find the "heavyweight" interior ministers - Bernard Cazeneuve from France and Thomas de Maizière from Germany, who sent an open letter to the Commission saying that "in exceptional circumstances, Frontex should also take initiative to deploy under its own responsibility rapid intervention teams at its external borders." (Politico.eu, 2015a).

The critique of the proposal from some of the high-rank politicians of EU member states only reflects the reality of the "old FRONTEX" when the member states were cautious about their sovereignty and would tend to 
rather increase the budget of the Agency than to provide it with genuine autonomy and competences necessary for its proper functioning.

Apart from the above mentioned public statements, there was a serious debate over Article 18 within the working bodies of the Council. We have tried to reconstruct these debates based on the data gathered from the officials of the member states ${ }^{3}$. Article 18 was the most debated article of the whole proposal and large number of Member States spoke about sovereignty and the responsibility for the control of the border.

Based on the debates within the Council we have tried to categorize the Member States into 3 separate groups. First groups are the Supporters, group of states that would initially support the proposal including the possible right to intervention and the strengthened role of the Commission. Second group would be the Cautious, state that would not openly criticize the article but would mention that sovereignty would have to be taken into account and the Member states should take part in the decisions. The third group would be the Opponents, a group of states that would be openly against the possible intervention. We are aware of the fact that distributing the states into three categories must be rather unprecise, but it is probably closest one could get, given the accessibility of the data. Also, the positions mentioned are rather initial positions of the member states that were subject to rapid change, as the negotiations were led under the pressure to establish EBCG quickly in order to react to the migration crisis and there was a significant shift in positions in the Council during the negotiations.

The argumentation of the first group of states was based on an assumption that European solution should be sought. This group included Germany as the largest receiver of migrants with strong interest in the functioning of external borders. Germany, together with France as its ally and also large receiver of migrants, would be the strongest supporter of the EBCG proposal, including Article 18. But these two countries were not alone, for example Portugal during the Council meeting, although aware of sovereignty problems, spoke about a necessity of a "shared competence“, as border protection is a European problem.

As for the group of Cautious states, these have mentioned during the initial debates that compliance of the Article 18 with the principle of sovereignty would have to be further enquired. This means that these states did not support the idea of right to intervene, but neither were they openly against it and pointed to the necessity to enquire further the relation of Article 18 to national sovereignty of the member states. The Cautious group would be the

${ }^{3}$ The discussions were confidential and the officials would not wish to be named. 
largest and if we count it together with the opponents, there would be a vast majority of member states that would have to certain extent problems with strong role of the European Commission in the intervention mechanism.

The last group of states, the Opponents, voiced severe concerns about how Article 18 touches national sovereignty. Their position would be that the proposal should not interfere with the national competence of the member states and their responsibility for border protection. They would question the very necessity of European mechanism and they would be against the initiative role of the European Commission set in the proposal. Typical members of this group were member states located at the exposed part of the external border, such as Italy, Greece, Spain, Malta or Bulgaria. Also Poland forms a large part of external border, although the country was not under heavy migratory pressure during 2015.

Contrary to the argument of frontline states this group also included Sweden as a state that was together with Germany one of the largest receivers of migrants in 2015. Sweden and other Nordic country, Norway a non-EU Schengen member, were also quite critical to the right to intervene during the Council meetings.

Table 1: Positions of state towards the right to intervene (Article 18 of EBCG proposal) ${ }^{4}$

\begin{tabular}{lll}
\hline Proponents & Cautious & Opponents \\
\hline Germany & Romania & Greece \\
\hline France & Slovenia & Italy \\
Austria & Czechia & Hungary \\
Belgium & Latvia & Poland \\
Finland & Lithuania & Spain \\
& Croatia & Malta \\
& Estonia & Sweden \\
& Denmark & Bulgaria \\
& Slovakia & Norway (Schengen member) \\
\hline & Switzerland(Schengen member) & Cyprus \\
\hline
\end{tabular}

Source: Authors based on the public statements and discussions with officials

\footnotetext{
${ }^{4}$ United Kingdom and Ireland were not full members of Schengen due to their nonparticipation in Schengen agreement. Luxembourg and Netherlands were a presidency states when the proposal was mostly negotiated and as such thein positions are excluded as Theky could be biased.
} 
The examples of Italy, Greece and Spain present a significant shift in the perception of European border protection. Previously these states would be proponents of stronger competences of FRONTEX, in the discussions over EBCG mandate they belonged to strongest opponents of the right to intervene and the necessity to use "European" forces on the national borders of the member states. On the other side Poland, while being seed of FRONTEX, shows long-term resistance to any possible breach into sovereignty at borders that was also visible during the previous enlargements of the mandate of FRONTEX.

Soon after the talks started it proved to be unrealistic to proceed with the right to intervene in the way how it was proposed by the Commission, as the vast number of states was opposing it and others were also rather sceptical to it. The debate then moved to keep the key decision-making power on possible interventions in the Council, what was a "reaffirmation of member states' primary competence regarding the management of national borders"(Monar, 2017, p. 8).

The European Commission was thus unsuccessful with its attempt to gain more competences in border management, facing resistance of large amount of member states. The argument was, like in the cases described above, the sovereignty of member states and their prime responsibility for border protection, or more precisely, for internal security as stated by Article 72 of TFEU. The Article 18 was thus changed and the mechanism is similar to the Article 26 of Schengen Borders Code that covers the reinstatement of the internal borders and where the member states play crucial role (Rijpma, 2016, p. 18) in starting this ultima ratio solution.

\section{CONCLUSION}

Even though the migration pressure in the years 2015 and 2016 was high and the quickness with which the proposal transforming the "old FRONTEX" into a new EBCG was rather unprecedented, the logic of the member states in the Council didn't change much vis-a-vis the previous debates over the mandates of FRONTEX. State sovereignty remained the most discussed issue with many member states unwilling to pass more competences to the Union level. And in the end, the member states were successful in keeping control over the functioning of EBCG.

In this paper we tried to identify the proponents and opponents of the mechanism included in Article 18. As for the proponents the biggest role was played by the Franco-German tandem. Both countries were affected by 
the migratory flows and at the same time they were not countries of entry for migrants, making application of the right to intervene against them unlikely. Their position was to keep the external borders under control as much as possible and to avoid repeating problems between FRONTEX and a member state at the border, such as in the case of Greece in 2015.

Large part of EU states raised certain concerns about sovereignty, even though they did not explicitly stand against the Article 18, during the meetings in the Council. The largest opponents of the right to intervene, that would openly question both the very need of such a right and the position of the European Commission within the mechanism, were mostly the "frontline" states. These states drew objections toward the right to intervene as they perceived it as endangering their sovereignty. Countries such as Italy, Greece or Hungary were directly on the main migration routes in 2015 and under heavy pressure. Spain had a recent experience with migration pressure before the crisis. As such, they could feel endangered by the possible use of the right to intervene against themselves. This would be particularly true for Greece that had difficulties cooperating with FRONTEX in 2015 and was also in conflict with some of the member states due to its (in)capacity to protect external border.

The result of these strong concerns about sovereignty was that the right to intervene with a strong role of the European Commission was absent from the final version of EBCG regulation and the decision-making powers for the mechanism moved to the Council. As in the previous situations, such as establishing the mandate of FRONTEX or enlarging it later, the member states were able to keep the responsibility for border protection with the newly established ECBG, showing how sensitive nature borders have. But the case has also shown differing views between states that were affected by the migration wave and states which wanted to create a mechanism how to strengthen external border protection and cooperation and states at the border, for which the protection of their sovereignty was principal.

\section{REFERENCES}

CARRERA, S. (2010). Towards a common European border service? Centre for European Policy Studies.

CARRERA, S. - Den HERTOG, L. (2016). A European Border and Coast Guard: What's in a name?, Centre for European Policy Studies.

CORTINOVIC, R. (2015). The Evolution of Frontex Governance: Shifting from Soft to Hard Law?. Journal of Contemporary European Research, 11(3). 
EKELUND, H. (2014). The establishment of FRONTEX: A new institutionalist approach. Journal of European Integration, 36(2), 99-116.

EPNacional.es (2016). Fernández Díaz ve con "reservas" un cuerpo europeo de fronteras que España no necesita "para nada", January $25^{\text {th }}$ 2016, Available on-line: http://www.europapress.es/nacional/noticiafernandez-diaz-ve-reservas-cuerpo-europeo-fronteras-espana-nonecesita-nada-20160125125221.html.

EURACTIV.COM (2015). Greek minister: New EU border force should assume full control of refugees, December 18th 2015, Available on-line: https:// www.euractiv.com/section/justice-home-affairs/interview/greekminister-new-eu-border-force-should-assume-full-control-of-refugees/. EUROPEAN COMMISSION (2003). Proposal for Council Regulation establishing a European Agency for Management Operational Cooperation at the External Borders.

EUROPEAN COMMISSION (2015a). Communication from the Commission to the European Parliament, the Council, the European Economic and Social Committee and the Committee of Regions: A European Agenda on Migration.

EUROPEAN COMMISSION (2015b). Communication from the Commission to the European Parliament, the Council, the European Economic and Social Committee and the Committee of Regions: Commission Work Programme 2016.

EUROPEAN COMMISSION (2015c). State of the Union 2015: Time for Honesty, Unity and Solidarity. Available online: http://europa.eu/rapid/ press-release_SPEECH-15-5614_en.htm.

EUROPEAN COUNCIL (1999). Tampere European Council 15 and 16 October1999: Presidency Conclusions.

EUROPEAN COUNCIL (2001). Presidency Conclusions: European Council Meeting in Laeken 14 and 15 December 2001.

GRABBE, H. (2000). The Sharp Edges of Europe: Extending Schengen Eastwards, International Affairs, Vol. 76, No. 3, 519-536.

HOBBING, P. (2005). Integrated Border Management at the EU Level. CEPS Working Documents No. 227, 1 August 2005.

HOUSE OF LORDS (2003). Proposals for a European Border Guard. London. JEANDESBOZ, J. (2008). Reinforcing the Surveillance of EU Borders: The Future Development of FRONTEX and EUROSUR. CEPS Challenge Paper No. 11, August 2008.

JONES, R. (2017). Interventions on the State of Sovereignty at the Border, Political Geography. 59: 1-10. 
JORRY, H. (2007). Construction of a European Model for Managing Operational Cooperation at the EU's External Borders: Is the FRONTEX Agency a decisive step forward. Challenge research paper, 6 .

KASPAREK, B. (2010). Borders and populations in flux: Frontex's place in the European Union's migration management. In The politics of international migration management, Palgrave Macmillan, London, pp. 119-140.

LEONARD, S. (2009). The creation of FRONTEX and the politics of institutionalisation in the EU external borders policy. Journal of Contemporary European Research, 5(3), 371-388.

MONAR, J. (2006). The project of a European border guard: Origins, models and prospects in the context of the EU's integrated external border management, in CAPARINI, M - MARENIN, O. Borders and Security Governance. Managing Borders in a Globalised World. Geneva, DCAF.

MONAR, J. (2017). Justice and Home Affairs, Journal of Common Market Studies, Vol. 55, p. 1-16.

MUNGIANU, R. (2013). Frontex: Towards a common policy on external border control. European Journal of Migration and Law, 15(4), p. 359 385.

NEAL, A. (2009). Securitization and risk at the EU border: The origins of FRONTEX, Journal of common market studies, 47(2), p. 333-356.

PARKES, R. (2015.) Borders. EU institutions fail to reconcile their agendas despite communitarisation. In TRAUNER, F. - RIPOLL, A. Policy change in the area of freedom, security and justice: how EU institutions matter, New York: Routledge, p. 53-72.

POLLAK, J. - Slominski, P. (2009). Experimentalist but not accountable governance? The role of Frontex in managing the EU's external borders. West European Politics, 32(5), 904-924.

POLITICO.EU (2015a). EU aims to boost border agency, December $11^{\text {th }} 2015$, Available at: https://www.politico.eu/article/eu-aims-to-boost-borderagency/.

POLITICO.EU (2015b). Countries balk at EU border force proposal, December $15^{\text {th }}$ 2015, Available at: https://www.politico.eu/article/countries-balkat-eu-border-force-proposal-migration-security-frontex/.

RAMBOLLl \& EURASYLUM (2015). External Evaluation of the Agency under Art. 33 of the Frontex Regulation. Available at: https://frontex.europa. $\mathrm{eu} /$ publications/frontex-evaluation-and-final-report-pRYblu.

REUTERS.COM (2015). EU's Frontex agency to help guard Greece-Macedonia border, $3^{\text {rd }}$ December 2015, Available at: https://www.reuters.com/ article/us-europe-migrants-greece-frontex/eus-frontex-agency-to-help- 
guard-greece-macedonia-border-idUSKBN0TM2B120151203.

RIJPMA, J. (2010): Frontex: Successful Blame Shifting of the Member States?, Real Institut Elcano Paper.

RIJPMA, J. (2016). The proposal for a European Border and Coast Guard: evolution or revolution in external border management?, Study for the LIBE Comittee.

RUDOLF, C. (2005). Sovereignty and Territorial Borders in a Global Age, International Studies Review, Volume 7, Issue 1, 1-20.

UNISYS (2014). Study on the feasibility of the creation of a European System of Border Guards to control the external borders of the Union. Available at: http://ec.europa.eu/geninfo/query/resultaction. jsp?QueryText=feasibility+study+ESBG\&op=Search\&swlang=en\&form build_id=form-lgJyPT65gKSWWn3KA7tkdel1Pj7J971npNEo47LDbtk\&f orm_id=nexteuropa_europa_search_search_form.

ZAIOTTI, R. (2008). Cultures of Border Control: Schengen and the Evolution of Europe's Frontiers, Toronto, University of Toronto.

WOLFF, S. - SCHOUT, A. (2013). Frontex as agency: More of the same?. Perspectives on European Politics and Society, 14(3), 305-324.

WSWS.ORG (2015). EU plans further crackdown on refugees, December $17^{\text {th }}$ 2015, Available on-line: https://www.wsws.org/en/ articles/2015/12/17/eupl-d17.html. 